\title{
Pemberdayaan Warga Binaan Lembaga Pemasyarakatan Kelas II Kerobokan Melalui Pelatihan Tata Boga dan Patiseri
}

\author{
${ }^{1 *}$ I Gede Astawa, ${ }^{2}$ Wayan Sukita, ${ }^{3}$ I Made Sujana \\ Akademi Pariwisata Denpasar, 1,2,3 \\ *Email: gedeastawa@akpar-denpasar.ac.id ${ }^{1}$, wayansukita@akpar-denpasar.ac.id, \\ madesujana@akpar-denpasar.ac.id
}

\begin{abstract}
ABSTRAK
Pemerintah melalui Pasal 7 ayat (2) Undang-undang Nomor 12 Tahun 1995, tentang Pemasyarakatan, menetapkan aturan tentang pembinaan dan pembimbingan warga binaan pemasyarakatan. Merujuk peraturan tersebut, Akademi Pariwisata Denpasar melalui kegiatan Pengabdian kepada Masyarakat $(\mathrm{PkM})$ memberikan pelatihan tata boga dan patiseri kepada para warga binaan di Lembaga Pemasyarakatan Kerobokan. Pelatihan ini dilaksanakan selama 6 hari, dari tanggal 29 Juli - 3 Agustus 2019, dengan jumlah mitra sebanyak 20 orang. Pelatihan ini dilaksanakan dengan tiga pokok materi, yakni pengetahuan dasar tentang tata boga dan patiseri, pengolahan, dan penyajiannya. Tujuan dari pelatihan ini adalah untuk memberdayakan para mitra untuk melakukan wirausaha mandiri pasca pembebasan dari Lembaga Pemasyarakatan. Di samping itu, dalam masa tahanan masih berlangsung, para mitra bisa melakukan usaha kecil berupa pembuatan masakan dan kue yang dijual di kantin LP. Pelaksanaan kegiatan ini dievaluasi oleh tim pelaksana PkM dengan teknik observasi dan wawancara dengan para mitra. Hasil evaluasi menunjukkan bahwa pelaksanaan pelatihan ini sesuai dengan sasaran yang diharapkan dan mendapat respons positif dari mitra. Sebagai tindak lanjut evaluasi kegiatan, Akademi Pariwisata Denpasar akan melaksanakan kembali PkM pada periode berikutnya dengan menyasar optimalisasi penjualan makanan dan kue yang dibuat oleh mitra sebagai usaha kecil yang dilakukan dari dalam LP.
\end{abstract}

Kata kunci : lembaga pemasyarakatan, patiseri, pemerdayaan, tata boga, warga binaan

\section{ABSTRACT}

The government, through Article 7 paragraph (2) of Law Number 12 of 1995, concerning correctional facilities, establishes regulations regarding the formation and guidance of correctional prisoners. Referring to the regulation, Denpasar Tourism Academy through Community Service Activities provides culinary and patisserie training to inmates at the Kerobokan Penitentiary. This training was held for 6 days, from July 29 - August 3, 2019, with 20 partners. This training was carried out with three subject matters, namely basic knowledge for culinary and patisserie, cooking practice, and serving the food. The purpose of this training is to empower partners to do independent entrepreneurship after being free from the prison. In addition, while the detention period is still on going, the partners can conduct a small business making dishes and cakes sold in the prison canteen. The Community Service Activities team in act evaluated the carrying out of this program by using observation 
technique and interview with the partners. The results of the evaluation show that the program meets with the goal expected and gets positive responses from the parners. As the follow up of the evaluation, Denpasar Academy of Tourism will reconduct a community service activity for the next period with the target of optimalizing the selling of the dishes and cakes made by the partners as a small business done in the prison.

Key words: empowerment, culinary, patisserie, prison, prisoners

\section{PENDAHULUAN}

Merujuk ketentuan Pasal 7 ayat (2) Undang-undang Nomor 12 Tahun 1995 tentang pemasyarakatan, pemerintah telah menetapkan Peraturan tentang Pembinaan dan pembimbingan para nara pidana (napi), yang selanjutnya disebut dengan warga binaan pemasyarakatan (http://bphn.go.id/data/documents/99pp03 1.pdf). Undang-undang ini secara eksplisit menyatakan peran pemerintah dalam memberdayakan warga binaan supaya memiliki kecakapan hidup yang bisa digunakan untuk menjalani kehidupan normal saat kembali ke masyarakat. Pemerintah, bersama unsur-unsur kelembagaan lainnya, berupaya memberikan berbagai macam bentuk pembinaan dan bimbingan agar para warga binaan pemasyarakatan, yang berasal dari berbagai macam kasus dan latar belakang sosial ekonomi, dapat kembali ke masyarakat untuk melangsungkan kehidupan secara normal setelah selesai menjalani masa hukuman. Beberapa skema pembinaan yang diberikan di samping bertujuan untuk meningkatkan kecakapan hidup, juga bertujuan untuk meningkatkan kualitas ketaqwaan kepada Tuhan Yang Maha Esa, sikap dan perilaku, serta kesehatan jasmani dan rohani warga binaan pemasyarakatan.

Untuk pelaksanaan pembinaan para warga binaan pemasyarakatan, pemerintah juga menggandeng organisasi-organisasi sosial dan perguruan tinggi untuk ikut ambil bagian melalui kegiatan Pengabdian kepada Masyarakat (PkM). Menurut undang-undang tentang pendidikan tinggi, PkM adalah kegiatan sivitas akademika yang memanfaatkan ilmu pengetahuan dan teknologi untuk memajukan kesejahteraan masyarakat dan mencerdaskan kehidupan bangsa (https://ft.untidar.ac.id/tri-dharma/).

Merujuk undang-undang perguruan tinggi di atas, Akademi Pariwisata Denpasar, melalui program kegiatan Lembaga Penelitian dan Pengabdian kepada Masyarakat (LP2M) berperan serta membantu pemerintah dalam upaya penyebaran ilmu pengetahuan dan teknologi kepada masyarakat. Oleh karena itu, melalui kegiatan PkM, Akademi Pariwisata Denpasar merancang beberapa skema kegiatan pengabdian yang bertujuan untuk memberikan pengabdian melalui kegiatan yang menyasar kecapakan hidup (life skill) para warga binaan Lembaga Pemasyarakatan (LP) Kerobokan.

LP Kerobokan sudah menyelenggarakan berbagai macam pelatihan kepada para warga binaannya. Dalam hal ini, Akademi Pariwisata Denpasar ambil bagian memberikan pelatihan kepada warga binaan di lembaga pemasyarakatan tersebut. Adapun alasan yang paling mendasar dilaksanakannya PkM di LP Kerobokan ini adalah adanya asumsi terhadap kembalinya para mantan warga binaan pemasyarakatan ini ke jalur kriminalitas apabila mereka tidak memiliki kecakapan hidup yang memiliki nilai 
ekonomis untuk menopang kehidupan secara normal sekembalinya ke masyarakat.

Di sisi lain, Bali yang mengandalkan Pariwisata sebagai penghasil devisa terbesar tentu harus didukung oleh situasi yang aman dan kondusif agar tetap bisa menarik wisatawan datang ke Bali. Hal ini sejalan dengan pernyataan Mahagangga, dkk. (dalam Kusumasanjiwani, dkk., 2017: 100) yang menyatakan bahwa suatu ancaman terhadap keamanan dan kenyamanan sangat berarti bagi setiap wisatawan karena mereka mencari kepuasan berwisata bukan mencari masalah dalam berwisata. Oleh karena itu, salah satu solusi yang disiapkan bagi para warga pemasyaratakan adalah membekali kecakapan hidup, sehingga bisa menekan adanya kemungkinan kembalinya para mantan warga binaan tersebut ke jalur kriminalitas yang mengganggu keamanan dan kenyamanan para wisatawan. Pelatihan kecakapan hidup ini menjadi salah satu poin penting yang dilakukan oleh Akademi Pariwisata Denpasar untuk membantu LP Kerobokan dalam rangka menyukseskan program-program pembinaan kepada para warga binaannya.

Sebelum dilaksanakan kegiatan ini, tim PkM terlebih dahulu melakukan identifikasi permasalahan ke LP Kerobokan agar bisa memilih skema pelatihan yang cocok dan memungkinkan untuk dilakukan sesuai dengan keahlian anggota tim. Identifikasi awal juga dimaksudkan agar kegiatan yang dilakukan memiliki kebermanfaatan terhadap para warga binaan yang mengikuti pelatihan. Hasil identifikasi awal yang ditemukan oleh tim PkM adalah (1) belum pernah dilaksanakan pelatihan tata boga dan patiseri di LP Kerobokan; (2) Kantin LP hanya menerima pasokan jenis makanan dan minuman dari luar LP, sehingga sangat terbuka peluang bagi para warga binaan untuk melakukan usaha kecilkecilan dengan menjual makanan dan kue di kantin LP; (3) LP Kerobokan tidak saja dihuni oleh warga binaan pribumi, tetapi juga dihuni oleh napi berkewarganegaraan asing. Kondisi ini bisa dijadikan peluang untuk menyediakan kue-kue yang sesuai dengan selera warga binaan asing tersebut; (4) pengembangan kantin sangat prospektif; dan (5) para warga binaan sangat potensial diberdayakan untuk menciptakan lapangan kerja di dalam LP sesuai minat dan bakatnya.

Dari hasil diskusi dengan para pimpinan LP Kerobokan, serta hasil identifikasi awal tim PkM, disepakati skema pelatihan keterampilan, yakni tata boga dan pateseri. Pelatihan ini diharapkan menghasilkan luaran yang bisa menciptakan wirausaha mandiri selepas para warga binaan tersebut dari LP.

Sasaran pelatihan tata boga dan pateseri bagi para warga binaan, yang selanjutnya disebut mitra, tidak saja untuk mencapai keterampilan pengolahan makanan dan kue tertentu, tetapi juga mempunyai sasaran sikap dan tata nilai. Hal ini sesuai dengan pernyataan Marzuki (2010: 99) bahwa tujuan pendidikan nonformal adalah adanya perubahan tingkah laku dan perubahan sosial para peserta. Perubahan tingkah laku ditujukan kepada para mitra, yaitu adanya perubahan setelah ada intervensi pemberian pengetahuan, keterampilan, nilai dan sikap.

\section{RUMUSAN MASALAH}

Para warga binaan yang sudah dibebaskan sering mengalami kesulitan mendapatkan pekerjaan pada perusahaan atau institusi tertentu. Hal ini sering 
disebabkan oleh citra negatif mantan warga binaan pemasyarakatan di mata penyedia lapangan pekerjaan, di samping ketidakpunyaan keterampilan yang memadai di bidang tertentu. Berdasarkan analisis situasi dan identifikasi permasalahan terhadap mitra, maka perumusan masalah pada kegiatan pengabdian ini adalah (1) upaya memberikan pengetahuan dasar tata boga dan patiseri; (2) pemberian metode/praktik pengolahan makanan dan kue yang mempunyai nilai komersil; (3) upaya pemberian tata cara penghidangan makanan yang memenuhi standar hygiene dan sanitasi.

\section{METODE}

Pelatihan tata boga dan patiseri ini diikuti oleh 20 orang warga binaan lakilaki di Lembaga Pemasyarakatan Kelas II Kerobokan, Kuta Utara, Badung, yang berlangsung dari tanggal 29 Juli sampai dengan 3 Agustus 2019. Untuk mengoptimalkan pelatihan ini, mitra dibagi menjadi dua kelompok, yakni kelompok boga dan kelompok pateseri. Masingmasing kelompok berjumlah 10 orang. Metode kegiatan ini dilakukan melalui metode ceramah, diskusi, dan praktik. Kegiatan ini dilakukan dengan materi sebagai berikut.

a. Pengetahuan dasar tata boga dan patiseri, beserta pengenalan bahan dan alat mengolah masakan atau kue;

b. praktik pengolah makanan dan kue;

c. praktik penyajian makanan; dan

d. evaluasi kegiatan.

\section{PEMBAHASAN}

Tata boga adalah seni mengolah masakan yang meliputi segala kegiatan yang berkaitan dengan masak memasak, mulai dari persiapan bahan, pengolahan sampai dengan menghidangkan atau menyajikan makanan itu sendiri, baik yang bersifat tradisional, maupun internasional. Sedangkan patiseri adalah salah satu cabang dari tata boga yang khusus mempelajari tentang seluk beluk membuat kue, mulai dari penyiapan bahan, pembuatan, penghiasan, hingga penyajian, baik kue tradisional, kontinental, maupun oriental. patiseri, praktik pengolahan makanan dan kue, dan penghidangan makanan dan kue.

Capaian dari pelatihan tata boga dan patiseri ini adalah (1) mitra memiliki keterampilan dasar mengolah makanan dan kue; (2) mitra dapat membuka usaha pembuatan masakan dan kue dalam masa tahanan masih berlangsung yang dijual di kantin LP, baik dilakukan secara mandiri maupun berkelompok; (3) mitra dapat memanfaatkan keterampilannya untuk menciptkan lapangan kerja mandiri setelah bebas dari LP Kerobokan.

Pelaksanaan kegiatan PkM yang diselenggarakan oleh LP2M Akademi Pariwisata ini melibatkan 5 orang dosen dan 2 orang mahasiswa, yang dapat dilihat pada tabel 1 berikut.

\section{Tabel 1. Tim PkM Tata Boga dan Patiseri di LP Kerobokan}

\begin{tabular}{|c|l|l|}
\hline No. & \multicolumn{1}{|c|}{ N a m a } & \multicolumn{1}{|c|}{ Keterangan } \\
\hline 1. & $\begin{array}{l}\text { I Wayan Sukita, S. } \\
\text { Sos., M. Pd. }\end{array}$ & $\begin{array}{l}\text { Koordinator } \\
\text { PkM }\end{array}$ \\
\hline 2. & $\begin{array}{l}\text { Dr. I Gede Astawa, } \\
\text { S. Pd., M. Hum. }\end{array}$ & $\begin{array}{l}\text { Sie } \\
\text { Dokumentasi } \\
\text { dan } \\
\text { Publikasi }\end{array}$ \\
\hline 3. & $\begin{array}{l}\text { Chef I Made Sujana, } \\
\text { A. Par., M. Par. }\end{array}$ & $\begin{array}{l}\text { Instruktur } \\
\text { tata boga }\end{array}$ \\
\hline 4. & $\begin{array}{l}\text { Chef I Wayan } \\
\text { Putrayasa }\end{array}$ & $\begin{array}{l}\text { Instruktur } \\
\text { patiseri }\end{array}$ \\
\hline 5. & $\begin{array}{l}\text { Chef Ari Darmawan, } \\
\text { SE. }\end{array}$ & $\begin{array}{l}\text { Instruktur } \\
\text { tata boga }\end{array}$ \\
\hline
\end{tabular}




\begin{tabular}{|c|l|l|}
\hline 6. & $\begin{array}{l}\text { Intan Indah Sari } \\
\text { (Mahasiswi) }\end{array}$ & $\begin{array}{l}\text { Pendamping } \\
\text { patiseri }\end{array}$ \\
\hline 7. & $\begin{array}{l}\text { I Gede Sugiarta } \\
\text { (Mahasiswa) }\end{array}$ & $\begin{array}{l}\text { Pendamping } \\
\text { tata boga }\end{array}$ \\
\hline
\end{tabular}

Dalam pelatihan boga dan patiseri ini, mitra diberikan tiga materi utama, yakni pengetahuan dasar tata boga dan patiseri, praktik pengolahan makanan dan kue, dan penghidangan makanan dan kue.

\section{A. Pengetahuan Dasar Tata Boga dan Patiseri}

Pada hari pertama, tanggal 29 Juli 2019, sebelum melakukan praktik boga dan patiseri, seluruh mitra dikumpulkan di ruang serba guna untuk mengikuti kelas tentang pengetahuan dasar tata boga dan patiseri. Mitra diberikan materi tentang (1) pemilihan bahan olahan yang baik; (2) cara memotong daging dan sayuran; (3) cara membuat adonan kue yang benar; (4) langkah-langkah kerja pengolahan; dan (5) standar hygiene dan sanitasi. Kelas ini berlangsung selama 120 menit dengan metode ceramah dan diskusi. Untuk mempercepat pemahaman mitra, instruktur menyertakan sampel bahan-bahan yang digunakan sebagai bahan dasar untuk praktik.

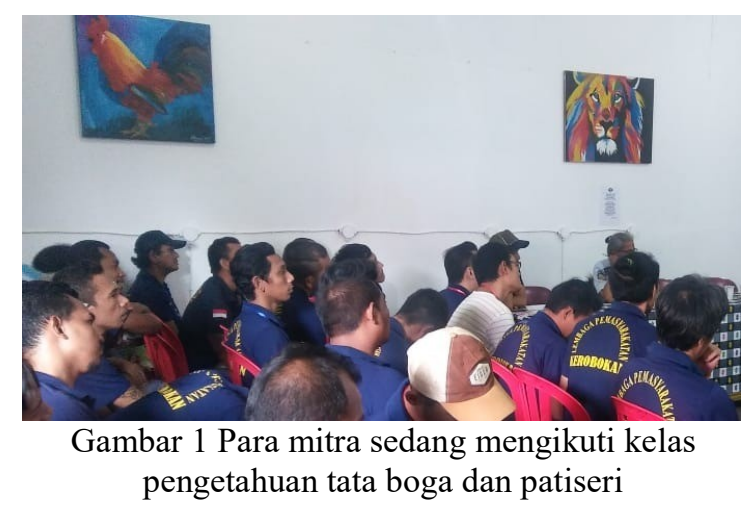

\section{B. Praktik Pengolahan Makanan dan Kue}

Setelah memperoleh pengetahuan dasar tentang tata boga dan patiseri, mitra dibagi menjadi dua kelompok, yakni 10 orang menjadi kelompok tata boga, dan 10 orang menjadi kelompok patiseri. Langkah pelatihan yang diterapkan oleh intruktur adalah (1) penyiapan peralatan memasak; (2) penyiapan bahan-bahan memasak dan kue; (3) resep masakan dan kue; (4) teknik memotong daging dan sayuran dan teknik membuat adonan; dan (5) proses pengolahan makanan dan kue.

Keberhasilan kegiatan memasak banyak ditentukan oleh kegiatan mice en place 'persiapan yang dilakukan sebelum proses memasak' (Batono dan Ruffino, 2006: 27). Oleh karena itu, instruktur juga memberikan pengetahuan tentang pentingnya mice en place tersebut dilakukan dengan baik sebelum proses memasak berlangsung.

Menu yang dipraktekkan dalam PkM ini adalah seperti tabel 2 berikut.

\section{Tabel 2. Daftar Menu Praktik Tata Boga dan Patiseri}

\begin{tabular}{|l|l|l|l|}
\hline \multicolumn{4}{|c|}{ Hari Pertama (29 Juli 2019) } \\
\hline \multicolumn{3}{|c|}{ Tata Boga } & \multicolumn{2}{|c|}{ Patiseri } \\
\hline 1. & $\begin{array}{l}\text { Semur daging } \\
\text { sapi }\end{array}$ & 1. & $\begin{array}{l}\text { Breafast role + } \\
\text { pan cake }\end{array}$ \\
\hline 2. & $\begin{array}{l}\text { Sambal } \\
\text { goreng hati, } \\
\text { ampela, } \\
\text { kentang }\end{array}$ & 2. & $\begin{array}{l}\text { Marble cake }+ \\
\text { banana roll } \\
\text { (chocolate) }\end{array}$ \\
\hline \multicolumn{3}{|c|}{ Hari Kedua (30 Juli 2019) } \\
\hline 1. & $\begin{array}{l}\text { Telor pindang } \\
\text { 2. 1. }\end{array}$ & $\begin{array}{l}\text { English cake }+ \\
\text { singkong keju }\end{array}$ \\
\hline 2. & $\begin{array}{l}\text { Gurame nyat- } \\
\text { nyat }\end{array}$ & 2. & $\begin{array}{l}\text { Muffin }+ \\
\text { coconut cake }\end{array}$ \\
\hline \multicolumn{3}{|c|}{ Hari Ketiga (31 Juli 2019) } \\
\hline 1. & $\begin{array}{l}\text { Ayam goreng } \\
\text { tepung sauce } \\
\text { asam manis }\end{array}$ & & Donut kentang \\
\hline 2. & Kare Ayam & & Kue lapis legit \\
\hline
\end{tabular}


Pada tiga hari pertama, instruktur yang dibantu oleh mahasiswa memberikan panduan tata cara memasak makanan dan kue kepada mitra. Instruktur memberi petunjuk, penjelasan, dan memberi contoh. Keterlibatan instruktur dengan mitra adalah $50 \%$. Tiga hari selanjutnya, yakni tanggal 1 - 3 Agustus 2019, mitra praktik mengolah makanan dan kue secara mandiri sesuai dengan kelompoknya. Instruktur hanya sebagai fasilitator saja, tidak terlibat langsung dalam proses pengolahan makanan dan kue; namun, sekali waktu instruktur memberikan petunjuk bila diperlukan. Instruktur mencatat proses pengolahan makanan dan kue yang dibuat oleh mitra, mulai dari penyiapan bahan sampai makanan dan kue siap dihidangkan. Susunan menu yang diolah secara mandiri oleh mitra adalah pengulangan menu pada hari pertama sampai ketiga (sesuai dengan tabel 2 di atas). Instruktur mencatat masalah-masalah yang dihadapi oleh mitra dalam mengolah makanan dan kue tersebut.

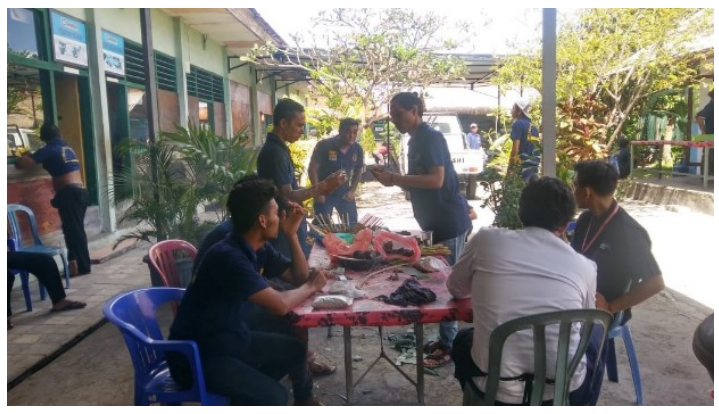

Gambar 2. Para mitra sedang praktik mengolah makanan

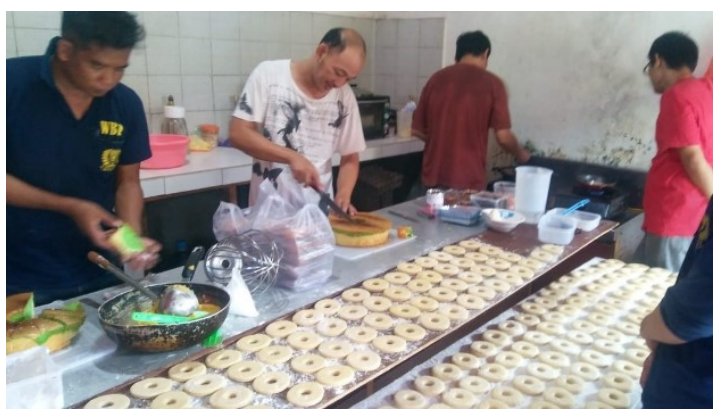

Gambar 3. Para mitra sedang praktik membuat kue

\section{Praktik Penghidangan}

Setelah proses

memasak (pengolahan) selesai, maka dilakukan tata cara penghidangannya. Sebelum mitra menghidangkan makanan dan kue yang sudah dihasilkan, instruktur memberikan penjelasan tentang bagaimana menyajikan makanan dengan baik. Instruktur menyebutkan beberapa aturan yang harus diikuti untuk berbagai situasi tertentu sehingga diperoleh penghidangan yang representatif dan cocok dengan karakter hidangannya. Praktik penghidangan yang dilakukan oleh mitra adalah (1) menata makanan dengan peralatan dan garnishing 'hiasan' yang sesuai; (2) penyesuaian jenis makanan dengan alat-alat hidangnya; dan (3) hygiene dan sanitasi.

Kendala dari praktik penghidangan ini adalah kurangnya peralatan yang dimiliki LP untuk menghidangkan makanan atau kue yang akan dihidangkan. Walaupun demikian, standar penyajian yang dilakukan oleh mitra sudah mengacu pada kebersihan dan sanitasi, serta aman untuk dikonsumsi.

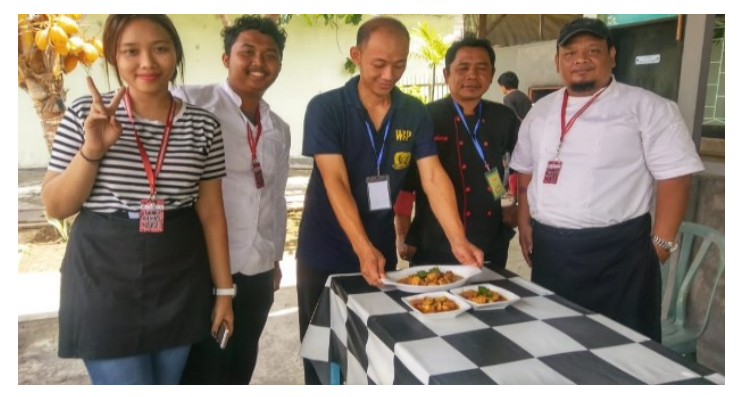

Gambar 4. Para mitra sedang praktik menghidangkan makanan

\section{Evaluasi}

Tahap akhir dari kegiatan $\mathrm{PkM}$ ini adalah melakukan evaluasi terhadap pelaksanaan pelatihan tata boga dan 
patiseri yang diikuti 20 mitra dari LP Kerobokan selama enam hari. Adapun evaluasi dilakukan secara klasikal oleh tim PkM terhadap pelaksanaan dua kegiatan, yakni pelatihan tata boga dan patiseri. Evaluasi dilakukan dengan metode observasi (pengamatan) pada saat mitra melakukan praktik mandiri yang dilakukan secara berkelompok. Evaluasi dilakukan oleh tim mulai dari tahap persiapan, proses, dan penghidangan. Di samping pengamatan, tim $\mathrm{PkM}$ juga melakukan wawancara dengan mitra. Adapun hasil evaluasi secara klasikal terhadap dua jenis kegiatan ditunjukkan pada tabel 3 berikut.

\section{Tabel 3. Evaluasi Kegiatan Pelatihan Tata Boga dan Patiseri}

Keterangan:

$1=$ Kurang, 2 = Cukup,

3 = Bagus, $4=$ Sangat Bagus

Memperhatikan tabel evaluasi kegiatan di atas, dapat ditarik simpulan bahwa kegiatan PkM ini sudah mencapai sasaran yang diharapkan oleh tim PkM. Hal ini dapat dilihat dari capaian dari 11 indikator yang dievaluasi sebagai berikut (1) terdapat 3 indikator $(27 \%)$ yang memeroleh predikat "Cukup", yakni pada metode memasak, cita rasa, dan kecepatan kerja; (2) terdapat 7 (64\%) indikator yang memeroleh predikat "Bagus", yakni indikator persiapan kerja, pengetahuan tentang menu dan bahan, penyajian, hygiene dan sanitasi, kebersihan meja, sikap kerja, dan rasa keigintahuan; (3) dan 1 indikator $(9 \%)$ yang memeroleh predikat "Sangat Bagus", yakni pada indikator kerja sama dalam tim.

Dari hasil wawancara dengan para mitra ditemukan gambaran bahwa mitra sangat senang mendapat kesempatan untuk mendapatkan keterampilan berupa tata boga dan patiseri. Mitra juga menyampaikan keinginannya untuk membuat makanan dan kue yang akan dijual di kantin LP setelah pelatihan ini selesai.

\section{SIMPULAN}

Kegiatan $\mathrm{PkM}$ berupa pelatihan kepada warga binaan di LP Kerobokan memberikan kontribusi yang sangat positif dalam memberdayakan mitra yang sedang menjalani masa hukuman supaya bisa memiliki keterampilan dalam bidang tata boga dan patiseri. Keterampilan yang dimiliki oleh mitra bermanfaat dalam dua hal. Pertama, peluang usaha kecil dalam bidang boga dan patiseri yang di jual di kantin LP. Kedua, membuka usaha kecil

\begin{tabular}{|l|l|l|l|l|}
\hline \multirow{2}{*}{\multicolumn{1}{|c|}{ Indikator }} & \multicolumn{4}{c|}{ Skor } \\
\cline { 2 - 6 } & 4 & 3 & 2 & 1 \\
\hline 1. Persiapan Kerja & & $\sqrt{ }$ & & \\
\hline $\begin{array}{l}\text { 2. Pengetahuan tentang } \\
\text { menu dan bahan }\end{array}$ & & $\sqrt{ }$ & & \\
\hline 3. Metode memasak & & & $\sqrt{ }$ & \\
\hline 4. Cita rasa & & & $\sqrt{ }$ & \\
\hline 5. Penyajian & & $\sqrt{ }$ & & \\
\hline 6. Hygiene dan sanitasi & & $\sqrt{ }$ & & \\
\hline 7. Kecepatan kerja & & & $\sqrt{ }$ & \\
\hline $\begin{array}{l}\text { 8. Kebersihan meja } \\
\text { memasak }\end{array}$ & & $\sqrt{ }$ & & \\
\hline 9. Kerja sama dalam tim & $\sqrt{ }$ & & & \\
\hline 10. Sikap kerja & & $\sqrt{ }$ & & \\
\hline 11. Rasa keingintahuan & & $\sqrt{ }$ & & \\
\hline
\end{tabular}
mandiri pasca pembebaskan mitra dari LP dan kembali ke masyarakat.

Mengamati hasil evaluasi pelaksanaan PkM pelatihan tata boga dan patiseri ini, maka kegiatan PkM dengan jenis pelatihan yang sama akan dilakukan kembali pada kegiatan $\mathrm{PkM}$ berikutnya dengan mengoptimalkan produksi makanan dan patiseri yang dijual di kantin LP. 


\section{UCAPAN TERIMA KASIH}

Terima kasih kepada Akademi Pariwisata Denpasar yang telah membantu, baik secara moral maupun finansial kegiatan $\mathrm{PkM}$ ini sehingga bisa dilaksanakan dengan baik dan mendapat respon baik dari pihak Lembaga Permasyarakatan Kerobokan selaku mitra kegiatan. Selanjutnya, ucapan terima kasih juga penulis sampaikan kepada tim LP2M Akademi Pariwisata Denpasar atas kerja samanya yang solid dalam mendukung setiap kegiatan penelitian dan pengabdian. Selanjutnya, penulis juga mengucapkan terima kasih kepada Kepala LP Kerobokan yang sangat kooperatif dalam menyukseskan kegiatan PkM ini.

\section{DAFTAR PUSTAKA}

Bartono, P.H. dan Ruffino E.M. 2006. Dasar-dasar Food Product: Panduan untuk Uji Kompetensi. Yogyakarta: Andi Yogyakarta
Fakultas Teknik Universitas Tidar. 2020. "Tri Dharma Perguruan Tinggi" (online). Tersedia dari: https://ft.untidar.ac.id/tri-dharma/

Kusumasanjiwani, dkk. 2017. "Merancang Lembaga Pemasyarakatan Kerobokan Denpasar sebagai Daya Tarik Wisata" (artikel). Denpasar: Buletin Udayana Mengabdi, Volume 16 no. 2, Mei 2017, hlm. $100-106$.

Marzuki, Saleh. 2010. Pendidikan Nonformal. Bandung: Rosda

Presiden Republik Indonesia. 1999. "Peraturan Pemerintah Republik Indonesia Nomor 31 tahun 1999 tentang Pmbinaan dan Pembimbingan Warga Binaan Pemasyarakatan" (online) [diunduh 15 Juli 2020]. Tersedia dari: http://bphn.go.id/data/documents/99 pp031.pdf 